\section{Biodiversity and base values}

Gary K. Meffe

Most biologists are familiar with terms such as 'hybrid vigour' and 'cross fertilization', and we generally understand the significance of among-population gene flow and inbreeding avoidance. Even the layman has a vague understanding of these concepts, and speaks of 'bringing in new blood' to a domestic population that may be in decline. Outbreeding, provided it is not too extreme, is often beneficial to a population and can rejuvenate a 'tired' gene pool and reverse the ills of inbreeding depression; it can introduce new characteristics and increase vigour. These genetic concepts can, I think, also be useful when applied to entire fields of study. We in the conservation community could benefit from the experience, perspectives and world views of others, and perhaps avoid reinventing the wheel as we venture into new territories. I believe some cross-fertilization with other fields could enhance our conservation efforts.

At the 1996 combined meeting of the Ecological Society of America and Society for Conservation Biology, ecologist Gretchen Daily of Stanford University spoke in a Symposium entitled 'Human Population and Consumption: What are the Ecological Limits?' Her insightful talk, 'Natural resources: maximum sustainable use and maximum sustainable abuse', drew an important parallel between ecologists and economists. She argued that ecologists and conservation biologists frequently accuse economists of 'externalizing' entities - such as environmental sources and sinks - that are troublesome or inconvenient to their models by simply placing them in 'black boxes' external to the models. Yet, she argued, conservationists are just as guilty of externalization by focusing on the parts of environmental problems that interest them - such as biodiversity, genetic losses or fragmentation-while conveniently ignoring other aspects of the problem that are vital and driving forces-such as human demands, economic processes, social problems, poverty and so forth. Her message was that conservation biologists need to get beyond their disciplinary boxes, and understand and appreciate other realms of human endeavour. That is, we need to cross-fertilize with other disciplines to develop more vigorous approaches to problem solving, and avoid problem definitions that are too narrow (e.g. ecological losses) and that thus constrain the discovery of potential solutions. I agree.

Over the last two years I have been rewarded with a 'cross-fertilization' of sorts, and my world view on conservation problems has been expanded as a result of exposure to a very different field than the various biological sciences I studied throughout my career. This came about as a result of working with my colleague Tim Clark of Yale University and the Northern Rockies Conservation Cooperative. He introduced me to a field of study known as the policy sciences, developed over the middle third of this century by Harold D. Lasswell and his colleagues. In a useful summary of the field (A Pre-View of Policy Sciences, 1971; American Elsevier Publishing Co., New York), Lasswell lays out issues and ideas in social thinking that $I$ believe may prove critical in addressing and solving global conservation issues. His work is far too comprehensive to explore here in any depth, but there are a few critical points that are worth relating.

Lasswell provided a simple model to describe the general social process that societies undergo. He said that the essence of all social process may be summarized as follows: participants (individuals or groups) seek to maximize values (gratify outcomes) by utilizing institutions that affect resources. If this general description is true, and because social process so obviously affects biodiversity and the health of ecosystems, then it argues that clearer understanding of this process could only help biodiversity conservation, both by comprehending motivations behind the general social process and by better incorporating conservation into that process. In other words, we need a better appreciation of what it is that individuals and groups seek - what outcomes or values they attempt to gratify - to have a 
greater chance of protecting the things that we value.

In what is to me a key revelation, Lasswell lists eight 'base values' that all humans seek, regardless of their culture, age or community standing. These eight values are: power, enlightenment, wealth, well-being, skill, affection, respect and rectitude. Power is the ability to make decisions that affect your life; enlightenment is the seeking of knowledge; wealth is ownership of resources, be they symbolic (money) or real; well-being is pursuit of health, safety and comfort; skill is the pursuit of proficiency in some area; affection involves love, friendship or loyalty; respect is the receipt of recognition from others; and rectitude is the pursuit of religious or moral standards.

These categories describe what all people seek to achieve in life, although they are pursued at different mixtures and levels by different people, and they can either be indulged or deprived by the social process. Thus, business leaders or politicians may be motivated largely by power or wealth, but nevertheless seek some level of respect and affection, and have some rectitudinal standards. In their pursuit of wealth they may indulge and share with others or deprive them of a fair share of this value. Academics or Buddhists may largely seek enlightenment and skill, and readily share it with others, but they still require some minimum levels of wealth and well-being in order to function.

Indulgence in all eight values seems to add up to freedom, because a person with sufficient levels of each of these values may be said to be free from pernicious social constraint. Deprival of any values results in deprivation of some level of freedom. For example, someone in prison for a minor offence is temporarily denied power, wealth, affection, respect, and perhaps other values; a prisoner of war who is inhumanely treated may be denied all eight values.

The relevance of these base values to us is that conservation efforts that deny one or more of these values to some people (and that thus deny some aspect of freedom) are less likely to be supported and succeed than are efforts that understand and gratify these values.
For example, the Endangered Species Act in the United States is repeatedly under attack by individuals, often private landowners, who feel threatened by the Act because they believe (often erroneously) that its provisions may deny them full use of their property. Their wealth and power thus are potentially denied (at least in their minds), and conflict over endangered species erupts. Similarly, harvest regulations for marine fisheries, or clear-cut restrictions in old-growth forests, tread heavily on the values of wealth, skill and well-being for many people, and thus are often resisted.

Conversely, lack of conservation often denies base values. These denied values can be restored when good stewardship is in place, and that is perhaps one of the great hopes for conservation. For example, we know that many free ecosystem services, such as water and air purification, soil building, storm protection, pollination and so forth satisfy several base values. Surely, crop pollination by hymenoptera is responsible for much wealth, power, well-being, skill and respect throughout the world. Couched in these terms, it should be easier to build public support for programmes that restore ecosystems, and thus their services, and gratify human base values. It is in humanity's most basic and selfish interests that this be done, and that is an easier sell than arguments about scientific value, morality or species diversity, as important as those arguments may be. When species diversity or habitat protection indulges one or more of the eight base human values, it stands a much higher chance of support than when it deprives one or more values.

Of course, we cannot always indulge individual values when the larger social good is in jeopardy. Thus, we restrict certain actions (such as logging or pollution) that would otherwise result in wealth or skill for some if those actions deny values such as well-being or rectitude for others. Law and regulations must continue to play a central role in environmental protection. However, where satisfaction of human base values is congruent with good stewardship, we should sieze the opportunity. 
This cross-fertilization among different perspectives seems a fertile area for conservation, for there is much to be learned about the human mind and spirit that remains to be incorporated into our collective efforts. The more we can glean from fields such as the policy sciences, sociology, economics, anthropology, law and others, the better equipped we will be to mount the global efforts necessary to incorporate species diversity and human needs into a compatible package. If we ignore the latter, if we choose to remain within the narrow constraints of our particular disciplines, then I fear we not only have neglected an important tool, but surrendered much of biodiversity to base values that we failed to comprehend and may also begin to exhibit the signs of inbreeding depression that we know so much about.

Gary Meffe is a Professor at the University of Georgia and the Savannah River Ecology Laboratory, and is senior author of Principles of Conservation Biology (Sinauer Associates, 1994).

\section{INEWS AND VIEWS}

\section{Important findings by FFI team in Kerinci Seblat, Sumatra, Indonesia}

Extending along $345 \mathrm{~km}$ of the volcanic Barisan mountain chain, which runs from the south-east to the north-west of the Indonesian island of Sumatra, the Kerinci Seblat National Park covers, in theory at least, $14,847 \mathrm{sq} \mathrm{km}$. Ranging in altitude from $35 \mathrm{~m}$ to the $3805-\mathrm{m}$ peak of Mt Kerinci, it is Indonesia's largest national park and one of the most species rich of Sumatra's national parks. In 1993, 43 of Sumatra's 47 key mammal species and 8 of the 12 key birds were recorded as present in the park. Yet, with the exception of its higher peaks, where endemism is presumed to be concentrated, Kerinci-Seblat has been little studied in recent years. With the exception of a few sample surveys and visits by collectors in the early part of the century, the only recent long-term faunal field work has concentrated on the park's few surviving Sumatran rhinoceros Dicerorhinus sumatrensis.

When a three-person FFI team started fieldwork in the park in 1995, little was known about the status and distribution of much of the park's fauna, and the number of bird species recorded stood at just 161 . By January 1997 , the team had confirmed the number of terrestrial bird species as 285 , while 23 species of mammal had been photographed, including
18 of Sumatra's key species. Thirty-three of Sumatra's key mammal species have been clearly seen, many on multiple occasions; this total excludes flying squirrels, some of which can be difficult to identify. Some animals known to occur in the park remain elusive; the hog-badger Arctonyx collaris, for example, has been neither photographed nor seen-although its footprints are encountered often.

The first real discovery was not faunal but floral, when the team found the very rare parasitic Rafflesia hasseltii (see front cover of this issue). This species is slightly smaller (less than $600 \mathrm{~mm}$ in diameter) but much more vividly coloured than the better-known and more common Rafflesia arnoldii, and appears confined to a single river valley at $620 \mathrm{~m}$. It is the first record for the species in the park and only the third site for the species this century.

The mainly secondary forest (it had been previously illegally logged) was also found to be richer faunistically than the team had expected. Tiger Panthera tigris, golden cat Felis temminckii, sun bear Helarctos malayanus, Malayan tapir Tapirus indicus, yellow-throated marten Martes flavigula and binturong Arctictis binturong were all recorded. Old rhino traps found at around $1100 \mathrm{~m}$, dating from the late 1950s, confirmed previous reports that rhino had once been present in grater numbers than today. One of the FFI team members, Ahmad Yanuar, has carried out the first detailed primatological study in Kerinci Seblat, on 